\title{
Article
}

\section{Conceptualizing a Social Sustainability Framework for Energy Infrastructure Decisions}

Whitton, John, Parry, Ioan, Akiyoshi, Mito and Lawless, William Available at http://clok.uclan.ac.uk/12065/

Whitton, John ORCID: 0000-0001-6391-5740, Parry, Ioan ORCID: 0000-00031847-3036, Akiyoshi, Mito and Lawless, William (2015) Conceptualizing a Social Sustainability Framework for Energy Infrastructure Decisions. Energy Research \& Social Science, 8 . pp. 127-138. ISSN 2214-6296

It is advisable to refer to the publisher's version if you intend to cite from the work. http://dx.doi.org/10.1016/j.erss.2015.05.010

For more information about UCLan's research in this area go to http://www.uclan.ac.uk/researchgroups/ and search for < name of research Group>.

For information about Research generally at UCLan please go to http://www.uclan.ac.uk/research/

All outputs in CLoK are protected by Intellectual Property Rights law, including Copyright law. Copyright, IPR and Moral Rights for the works on this site are retained by the individual authors and/or other copyright owners. Terms and conditions for use of this material are defined in the policies page.

\section{CLoK}

Central Lancashire online Knowledge www.clok.uclan.ac.uk

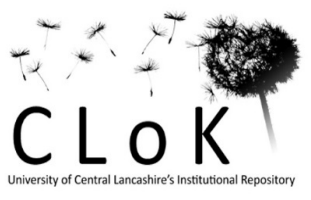




\title{
Conceptualizing a Social Sustainability Framework for Energy Infrastructure Decisions
}

\begin{abstract}
The concept of social sustainability is discussed in a wide range of literatures, from urban planning to international development. Authors agree a notion of social sustainability is difficult to define, comprising numerous component parts (criteria), such as community cohesion, human wellbeing, effective dialogue and the access that citizens have to those that make important decisions on their behalf. The definition and measurement of these criteria and the role of social sustainability in energy decision making is a contentious issue. We argue that a community led, asset based approach is required to achieve any sense of how social sustainability can be defined in a community setting within the context of energy developments. We propose a conceptual framework based on a process of community group prioritization and visioning. Our earlier research on public participation and the role of dialogue for nuclear energy development in the UK, US and Japan is used to demonstrate barriers to be overcome if our systemic model of social sustainability is to become a reality. We highlight the importance of fairness and justice, place based approaches and socio-energy systems, concluding that these are necessary to promote a community and institutional awareness of social sustainability for large energy developments.
\end{abstract}

Keywords: Social Sustainability; Deliberation; Community; Energy Infrastructure.

\section{Introduction}

This paper presents a conceptual framework for social sustainability; a framework and a form of sustainability that allows various stakeholder groups, through deliberation and community visioning [1-3], to agree priorities that contribute to energy decision making for strong and successful communities. Community visioning is a citizen-based planning process, whereby an issue is defined by diverse members of a community, community assets are identified, a desired future is determined, and an action plan to achieve this future is developed [3]. It is increasingly used as a community development technique; for example, to encourage more participatory democratic processes in community planning and development [4], to address urban deterioration in Northern Ireland [5], and in local area planning on the Gold Coast in Australia [2]. As Lachapelle, Emery and Hays [3: 178] note, the process "emphasizes community assets rather than needs", and identifies future opportunities for communities. 
The decisions made regarding the management of new and aging energy infrastructure are of local, national and international importance. Improved dialogue between industry and stakeholders can significantly impact upon the quality of decision-making [6], demonstrating a more democratic decision-making process. The literature supports democracy, in governance and society, to be a key theme of social sustainability and our conceptual framework [7]. In this paper, we evidence the shift in the nature of the energy stakeholder-industry relationship through reference to our work at UK nuclear sites [8-9], where there has been an increase in dialogue taking place but questions regarding the fairness of this dialogue for stakeholders.

The importance of and need for further research into understanding the perceptions, priorities, involvement and support of local residents regarding large scale energy infrastructure is evident, and Walker, Wiersma and Bailey [10] echo this in the following statement:

"How to ensure fair processes and just outcomes for local communities, and how to enhance the acceptability of energy generation facilities amongst local populations remain important areas of human-energy research." [p. 46]

However, in democracies, obtaining public consent for development of any kind is challenging. We demonstrate this through reference to our work at US nuclear sites, where open competition for consent for energy related developments appears to improve the quality of the scientific choices made and the stability of these choices with a public faced by adverse events [11]. We embrace the move towards a participatory-based form of dialogue in decisions rather than a technocratic 'top down', expert-led, 'one-way' form of consultation as we discuss with reference to our work in Japan. In our framework, dialogue is not only 'two-way', but multi-directional and dimensional, incorporating multiple stakeholders [12].Through the application of our framework, we aim to start to provide the tools required for communities to effectively engage and influence Government and Industry on decision-making that directly impacts upon them.

\subsection{Why is a Social Sustainability framework needed?}

The need for a conceptual framework to improve understanding of what social sustainability involves and requires has been acknowledged for some time. Lake and Hanson [13] emphasize this, whilst promoting urban sustainability: 
"Given the conceptual vacuity burdening much of the debate, the question is not whether sustainability can be resuscitated conceptually but what conceptual framework offers the greatest promise of constructive understanding. Given the term's co-optation by interests across the political spectrum, the question is not whether sustainability can be achieved but what must be achieved to assure sustainability" [p. 2]

Previous conceptual frameworks for social sustainability include those proposed by Yitfachel and Hedgcock [14] for urban social sustainability and Jones and Tonts [15] for rural social sustainability, the latter being an adaptation of the former. These present urban and rural sustainability as being influenced by social, environmental and economic components, in simple diagrams where these relationships are one-way, feeding into the urban or rural sustainability systems, without the self-reinforcing relationships proposed by Cuthill [2]. The factors contributing to the social component of both frameworks are identified as equity, community, and urbanality [14] or rurality [15]. This not only demonstrates how the understanding of key social sustainability components in the literature has progressed over the past two decades but also the lack of progression over the same period in developing an appropriate conceptual framework for social sustainability.

Cuthill [2] demonstrates a recent attempt to improve understanding of the social sustainability concept; employing an action research approach based on rapid urban growth in South Eastern Queensland, Australia. The author provides a framework employing theoretical, operational, ethical and methodological components deemed essential to regional social sustainability; social capital, social infrastructure, social justice and engaged governance respectively. This is similar to the conceptual framework presented here; similarly an action research approach, aiming to work with various social groups within a community to understand and acknowledge social issues that they prioritise rather than issues deemed by officials or other decision makers to be important.

In regard to sustainable decision-making for new energy projects, the work of Raven et al. [16-17] has informed our work. Managing social acceptance for new energy projects has highlighted the value of incorporating the views and contributions of local stakeholders, in order to anticipate and avoid potential problems with societal acceptance. The authors' ESTEEM model employs vision building techniques and identifies conflicting issues with stakeholders. The conceptual framework presented here is also based on generating an understanding of local stakeholder priorities and vision building to improve decision making. By doing so, later conflict may be avoided, as projects are able to develop more sustainably by incorporating a detailed understanding of stakeholder expectations and priorities, and formulating more socially acceptable options and solutions.

We theorize that the impact of a large infrastructure development on a community is more direct and tangible when compared to the regional and national scale. This is not to say that 
ecological and economic considerations are not of equal importance, but that social issues and potential social impacts at the community level should be given attention, understood in greater detail and incorporated further into local decision making processes. The result is more democratically informed and legitimate decision making, and potentially more sustainable at the community level. This does not generate a scenario to the extent of reflexive modernization [18], but it shares notions of this theory; working towards futures which are more desirable, to communities in this instance, rather than future scenarios that are pre-defined, to which people are forced to adjust to [19], and therefore, are likely more unsustainable.

\section{Conceptual Framework for Social Sustainability}

When discussing social systems such as a community, we distinguish between systems thinking and systemic thinking [20]. Rather than assuming knowledge that identifies a social system to be objective and one that can be readily identified and improved; we understand reality as the creative construction of human beings [21]. We have used this definition as a basis to conceptualize social sustainability, seeking to understand reality as the construction of people's interpretation of their experiences, in this case regarding energy infrastructure developments and their impacts on communities. Accepting the various traditions that comprise systems approaches to tackling complexity, as Systemists we aim to see the whole picture, entertaining shifts in perspective to reflect differing positions held by engaged observers [22]. By constructing mental models to create conceptual systems, interdependencies are highlighted. This approach seems particularly relevant when reflecting on large scale developments that affect communities over long periods of time. Energy developments, such as power stations (generation) and power lines (transmission) are an example of this. These have an operational lifetime of around 50 years, so impacts on a community can be intergenerational and variable, from gains in employment to a perceived loss in visual amenity.

Bijl [23] argues that social sustainability is instrumentally and intrinsically relevant to sustainable development, as "society needs a sense of community and commitment" (p.162). Multiple definitions have been developed such as those for urban planning [24-26], as researchers / practitioners seek to understand social sustainability and its sub-themes, such as well-being and democratic governance [7] or development, bridge and maintenance sustainability [27]. Social sustainability is a concept gaining recognition as being critical for sustainable development and societal prosperity. 


\subsection{Social Sustainability, Stakeholder Participation and Dialogue}

How do we ensure that social sustainability as a concept is incorporated into communityled decision-making? As previously discussed, we embrace the move towards a participatorybased form of dialogue to derive robust socially sustainable decisions over the long term. A substantial literature supports the notion that greater public participation in decision-making serves to significantly reduce conflict, leading to more robust decisions for large energy infrastructure developments. Less opportunity for public participation increases the likelihood of public opposition and delays to developments [28]. Such developments include nuclear waste repository siting [29], electricity transmission and infrastructure planning [30-31], wind energy developments [32], small hydropower projects [33] and rural renewable energy implementation [34]. The advantages of greater public participation are well documented, such as the participatory process adopted for nuclear waste management decisions in Sweden [35]. However, failure to sufficiently consider and involve the public can have negative consequences for similar projects, as has been the case in the Czech Republic [36], and in the UK [37], where a lack of trust has been shown to be a key factor in public uncertainty towards plans for a national nuclear waste repository, which we discuss later in this section. Similar effects have been found in regards to other large scale energy infrastructure in Europe. A recent study conducted by Aas et al. [38], believed to be the first cross-national comparative study into public acceptance of new high voltage power lines (HVPL), suggested that there is common public perception in the UK, Norway and Sweden of weak local resident involvement in planning and decision-making processes. In the UK, the study found significantly low levels of trust towards grid networks and operators, and consistently low levels of acceptance of HVPL developments, both locally and generally. The authors also note that the results of this and several other empirical studies, on HVPL and other large scale renewable energy projects [39-43], demonstrate that local acceptance is commonly lower than general acceptance.

We have made the basis of our approach clear; public participation and dialogue is essential to any notion of social sustainability. But who is this public, and who can we describe as a stakeholder in any decision either made by or on behalf of a community when seeking social sustainability? For the purpose of theorizing a social sustainability conceptual framework, this consideration is essential. The most common definitions of the term 'stakeholder' view these as any group or individual that can affect or is affected by a proposal, project or decision. This definition is broad and does not aim to categorize or understand any requirements that stakeholders may have. As Aaltonen et al. [44] discuss, stakeholder theory provides a solid starting point for identifying, classifying and categorizing stakeholders and understanding their behaviour in order to better manage them. Research usually adopts the perspectives of the organisation convening the engagement process rather than the participants, to describe and analyse the different stakeholder management strategies adopted. We have adopted an alternative definition of the term stakeholder presented by Mitchell et al. [45], referring to those 
individuals whose claims are perceived to be more salient in terms of power, legitimacy and urgency.

Accepting the definition, how this power, legitimacy and urgency is translated from communities to decision-makers through engagement practice is important if engagement with communities is to be considered a worthwhile exercise. Our UK case study example reviews the move in the UK towards open and accessible stakeholder dialogue and references recent work carried out with participants of the engagement process associated with the decommissioning of UK nuclear power station sites [46]. This highlighted the shift towards attempts at deliberative dialogue during engagement and provided a definition of deliberation based on the literature. The Author also highlighted the role of stakeholder influence (power) on decision making and relates this to the concept of fairness. The case study from Japan highlights the importance of a perception of fairness. Deliberation, influence and fairness are proposed as emerging themes in stakeholder theory (see our working definitions in Table 1) and contribute towards the conceptual framework for social sustainability. 


\begin{tabular}{|c|c|c|}
\hline $\begin{array}{l}\text { Key Themes and } \\
\text { Concepts }\end{array}$ & Working Definition & References to Literature \\
\hline Stakeholder & $\begin{array}{l}\text { An individual whose claims are } \\
\text { perceived to be more salient in terms of } \\
\text { power, legitimacy and urgency. }\end{array}$ & Mitchell et al. (1997) [45] \\
\hline Deliberation & $\begin{array}{l}\text { A process that "presumes and promotes } \\
\text { reciprocity which requires people to find } \\
\text { mutually acceptable ways of resolving } \\
\text { moral disagreements whilst maintaining } \\
\text { mutual respect". } \\
\text { Also; "deliberation is expected to lead } \\
\text { to empathy with the other and a } \\
\text { broadened sense of people's own } \\
\text { interests through an egalitarian, open- } \\
\text { minded and reciprocal process of } \\
\text { reasoned argumentation" }\end{array}$ & $\begin{array}{l}\text { Shapiro (1999) [47], also } \\
\text { Mendelberg (2002) [48] }\end{array}$ \\
\hline Dialogue & $\begin{array}{l}\text { Deliberation must occur through } \\
\text { 'dialogue' or 'rational discourse'. The } \\
\text { dialogue process is based in } \\
\text { Communicative Reason. }\end{array}$ & Rossi (1997) [49] \\
\hline Participation & $\begin{array}{l}\text { "When information is exchanged } \\
\text { between parties.........dialogue and } \\
\text { negotiation serve to transform the } \\
\text { opinions in the members of both } \\
\text { parties" }\end{array}$ & Rowe and Frewer (2005) [50] \\
\hline Fairness & $\begin{array}{l}\text { The "broad representation and } \\
\text { equalization of power and equity among } \\
\text { participants" }\end{array}$ & Beierle (2002) [51] \\
\hline Procedural Justice & $\begin{array}{l}\text { "demonstration of fairness and } \\
\text { righteousness........... in processes or } \\
\text { decision making procedures" }\end{array}$ & Walker et al. (2014) [10] \\
\hline
\end{tabular}

Table 1: Definition of key terms 
Political theorists and social scientists have traditionally argued that concepts related to public acceptance (e.g. fairness) are of greatest importance regarding participation in policy setting, while those arguing from an economic and scientific perspective have argued that the quality of the decision and process is more important (and often, that lay persons lacking knowledge should have little role to play in technical/scientific policy making) [52]. When discussing highly technical projects, the argument regarding the need for quality decisions, based on the best technical data available is hardly surprising. However, this technocratic approach to decision making has failed in the past when decisions made have been subjected to public scrutiny [9]. In this paper, we argue that this approach is not socially sustainable where there is a clear public interest. The option based on the pinnacle of technical excellence may not be acceptable to the wider public or appropriate in a community setting. This corresponds with notions of Post-Normal Science Theory [see 53-56], arguing that the scientific system must move beyond the traditional 'reductionist' approach, relying almost exclusively on industry or technical experts, deeming it as insufficient, and that the role of other stakeholders, and indeed the public, should be viewed as necessary if the scientific system is to be legitimate and democratic. As Funtowicz and Ravetz [54] argue, a post-normal science approach which promotes the collective production of knowledge, involving those "affected by the issue who enter into dialogue on it" [57:8], is appropriate when "facts are uncertain, values in dispute, stakes high and decisions urgent" [54: 744, cited in 57]. Such participatory approaches are particularly relevant when decision-making on issues involving or presenting potential risks to society, such as energy infrastructure, in particular nuclear power developments, are considered.

We acknowledge there are challenges with and limitations to participatory approaches. These can include a dearth of peoples' interest or time to participate in the process; an inability to sufficiently engage with, discuss or debate highly technical issues or concepts; potentially significant costs associated with organizing and conducting workshops or public engagement sessions with the ethical or social aspects of new technologies; consultation fatigue; and causing public mistrust if the process is seen to be merely a 'box-ticking exercise' for a predetermined decision, with no genuine opportunities to influence outcomes or decision-making [57-59]. We propose that by discussing and establishing the priorities of local stakeholder groups at an early stage, the dialogue is time-effective, locally relevant, focused towards specific stakeholder interests, and generates knowledge which can be utilized within a range of decision-making processes. If broad group priorities are understood, this could potentially reduce the amount of public consultations and engagement processes required within a given locale, particularly where multiple developments are occurring over a short time period leading to increased 'consultation density'. Therefore, there are also opportunities for mitigating consultation fatigue through reduced energy-related consultations, where similar topics may be discussed and consulted upon. 
According to Habermas [60-61] in his Theory of Communicative Action, good participation is seen as both fair and competent. But how does this fairness and competence translate to a conceptual framework of social sustainability? Beierle [51] states that fairness is achieved by broad representation and equalization of participants' power, whilst competence often involves the use of scientific information and technical analysis to settle factual claims. Other authors have disputed this equalization of participants' power as an ideal not always represented in deliberative practice. Van Stokkom [62] emphasises that deliberative processes to inform policy do not always meet equality and rationality ideals. Behind the ideal of rational dialogue between equal participants the author finds an interplay of power and emotion dynamics that can aid or impede deliberation.

In the UK, support for greater dialogue-based engagement from Central and Local Government, and Government agencies has increased in recent years, in order to encourage public involvement in decision-making processes to inform and influence a range of issues and policies [46]. Dryzek [19] highlights the 'deliberative turn' in democratic theory at the end of the twentieth century, in a move towards greater democratic legitimacy and involvement of those affected by collective decisions. Historically, a period of public consultation is considered by the United Kingdom (UK) Government to be the correct process in which to involve the public in the development of new policy and legislation [63]. The feedback received from the consultation informs the Government's decision making process, resulting perhaps in policy or legislative changes. When new plans are large-scale and considered controversial, a planning inquiry (with independent adjudication) is often the route taken to derive an outcome. As the UK Government has a majority stake in the nuclear industry, this consultative process and associated guidance has been adopted, however, there are examples where the industry has gone further than consultation.

Examples of industry-stakeholder dialogue in the UK include the decommissioning of Trawsfynydd [64]. This case study, where public participation contributed in selecting decommissioning options, is uncommon, in that it demonstrates local community involvement in nuclear decision-making processes. Cotton and Devine-Wright [31] echo this observation in their study of public engagement in electricity transmission infrastructure planning in the UK. They find that while network operators claim to support deliberative dialogue with the public, opportunities and evidence of such public engagement are lacking, with citizens perspectives remaining on the periphery of decision-making. Such involvement of local stakeholders has been suggested as vital to project management and development. Kemp et al. [65] describe various practices and techniques in stakeholder dialogue regarding nuclear waste management in the UK, and emphasise the importance of engaging fully with local stakeholder and community groups. Stakeholder dialogue has also been promoted as a critical component for biomass technology developments in the Netherlands [66], as for any large development with significant environmental impacts: 
'...in order to deal with complex environmental issues, structured stakeholder dialogues are needed that map out and articulate the various perspectives - values, interests, knowledge claims and underlying assumptions - that exist with regard to the issue' [p. 579].

However, appropriate public engagement and stakeholder dialogue remains to be a persistent issue for some energy infrastructure developments. For example, the UK study of Evans et al. [67], of proposals by supermarket chain ASDA for the construction of wind turbines in semi-rural areas, highlighted an inadequate 'business-as-usual' approach to engagement. This included presumptions made in regards to public perceptions of Renewable Energy Technology (RET) developments. Proposed legislation aiming to remove barriers to the development of infrastructure in the UK, such new nuclear power stations, may restrict progress in democratic decision making.

Within the context of participation associated with the UK nuclear legacy, the form of democracy administered by UK Central and Local Government does not provide stakeholders with the power to veto decisions by majority rule, nor require the decision maker to reach a consensus with stakeholders. However, the term 'influence' mentioned in the Energy Act of 2004 [68] seemed to give stakeholders an increased level of involvement in nuclear decisionmaking.

Whitton worked with community participants between 2007 and 2010 at a biannual UK wide gathering of stakeholders for the decommissioning of UK nuclear energy generation and reprocessing sites, to generate mixed methods research data on individuals' perceptions of the type of dialogue used to engage them and their perceived influence on decision making $[9,46]$. The findings from two questionnaires completed by 57 NDA stakeholders, followed by a sample of interviews, recorded that the ability of participants to express views, have fair engagement with NDA, understand other stakeholder positions and expect transparency regarding their influence was important to participants. Despite all of these being achieved in part, stakeholders remained confused regarding the extent of their influence on decisionmaking, their role in the process and the nature of the dialogue being implemented. Much of this is due to a lack of what the literature terms reciprocity: transparency regarding how the views of stakeholders influence strategy and associated decision making - if at all.

The UK Government's Managing Radioactive Waste Safely (MRWS) process (2008 2013) used consultation to identify volunteer communities for a deep geological repository. Three local authorities volunteered for the MRWS programme: Copeland and Allerdale Borough Councils, and Cumbria County Council. In January 2013, the three local authorities voted on whether to proceed to stage 4 of the process. The two boroughs voted in favour, but the county of Cumbria voted against continuing with the site selection process. Government had stated in 2011 that the site selection process would only continue if there was agreement at both borough and county level. The county's decision therefore ended the existing site 
selection process, and the Department of Energy and Climate Change (DECC) released a statement saying that the current site selection process has been brought to a close in West Cumbria [69].

Our US example is significantly different to the UK above. Here, we demonstrate the complexity of involving stakeholders in energy decisions. Chartered under the US Federal Advisory Committee Act, citizen advisors to the Department of Energy (DOE) are chosen to advise on nuclear site activities. There were 9 Citizen Advisory Boards (CABs) advising on waste management and environmental clean-up [70]. The DOE recommend that consensus rules are used when decision making: "To encourage the Board [of citizens] to listen carefully to all points of view and to work toward consensus" [71-72]. However, CABs are permitted to decide among themselves what system of decision making to use. As a result, in 2005 only four CABs operated under consensus rules, with five permitted by DOE to use majority rules. This provided an opportunity to investigate the stability of decisions made under each system of decision making. We focused on DOE's Hanford Site and its Savannah River Site (SRS).

The Hanford Citizens Advisory Board (HAB) draws its members from around DOE's Richland, WA, facility. Its members are nominated by different interest groups, for example, environmentalists, pubic organizations and governments. HAB adopted consensus rules, but a group consensus on decisions proved difficult and made HAB's advice and decisions less stable and subject to change. Minorities on both sides of an issue can block a decision, meaning that reaching concrete decisions at Hanford has proved difficult. As a result, very few policy changes at Hanford have accelerated the clean-up. A similar effect happened in the EU: "The requirement for consensus in the European Council often holds policy-making hostage to national interests in areas which Council could and should decide by a qualified majority" [73: 29].

SRS Advisory Board is a group of stakeholders from South Carolina and Georgia [74]. The SRS-CAB uses majority rules. Its 25 members are required to be a diverse cross-section of citizens near SRS. Comparatively, SRS-CAB had significantly more diversity but also more college graduates than other CABs across DOE [70]. Roughly 50 percent of CAB members live adjacent to SRS with another 10 percent within 50 miles, the balance drawn from among those who live downstream of SRS (e.g., Hilton Head, SC and Savannah, GA) [74]. The decisions and advice by SRS-CAB has proved stable and has not been subject to change. For example, regarding the closure of waste storage tanks at the site, it recommended: "Take extraordinary measures to meet or exceed the schedule for closure of Tanks 18 and 19 consistent with the FY 2012 closure schedule and not delay closure unless significant safety issues are raised." 1

\footnotetext{
${ }^{1}$ SRS CAB (2012, 1/24), "Need to Continue Ongoing Progress for Closure of Tanks 18 and 19".
} 
From our research, it would appear that active competition among ideas is a requisite for improved decision-making, with scientists and the public, especially in the face of adverse events. In his dissent, Justice Holmes [75] wrote that:

"the ultimate good desired is better reached by free trade in ideas--that the best test of truth is the power of the thought to get itself accepted in the competition of the market"

A large part of the problem with the deliberation model is its tacit assumption that decisionmaking can be studied as a rational, cooperative process. The empirical evidence contradicts this assumption by indicating that interdependence plays the key role in increasing uncertainty, in creating incomplete information, and in creating competitive alternative interpretations of actions and decisions. The role of participant consensus has been highlighted in our US case study, in this case leading to decision-making gridlock between participants. We concluded that a majority-based system of decision-making is more effective when technical, engineering based solutions are required [11]. Others recommend caution with this type of approach [76], demonstrating that although majority-based systems are a good starting point for deliberation, this may hinder active discussion among stakeholders, negatively affecting consensus formation when stakeholders aim to improve their satisfaction through a collaborative process. The authors state that:

"As the level of conflict among stakeholders intensifies, starting with an unpopular proposal can 'fuel the fire' of the deliberation and contribute to the consensus-building process, especially when stakeholders are willing or able to adjust their preferences in response to input from other participants" [p.100].

Our research in Japan demonstrates how the relationship between government agencies and citizens is broadly based on public relations rather than deliberative engagement. Japanese authorities make decisions on behalf of citizens, but they are unable to find the means to elicit public support. ${ }^{2}$ On the other hand, the individuals and communities have not been invited to the table of effective dialogue in spite of significant interest in the future of nuclear energy development, as evident in numerous mass demonstrations observed throughout the country after the Fukushima accident. Following the Fukushima Daiichi crisis, the government of Japan implemented a structural reform. The Nuclear and Industrial Safety Agency and the Nuclear Safety Commission were replaced with the Nuclear Regulation Authority in 2012. It remains to be seen whether and how the new organizational structure will address the longstanding issue of citizen participation in nuclear energy decision-making.

\footnotetext{
${ }^{2}$ Japan Today (2012, 3/19), "80\% in Japan support nuclear phase-out". Based on a survey conducted by Tokyo Shimbun (www.japantoday.com/).
} 
This dissatisfaction with a top down, technocratic policy of energy decision making has led to public "acceptance" becoming a divisive and controversial term when applied to nuclear energy and radioactive waste management policies [77]. The 2011 Fukushima Daiichi nuclear plant accident and its aftermath are the latest examples of enduring controversies. Outside of government and industry, few stakeholder perspectives were acknowledged; e.g., the risk of nuclear power plant failure in the event of the tsunami in warnings by seismologists prior to the 2011 earthquake went unheeded [78]. An expert on citizen participation cited the example of the Danish Board of Technology and pointed out that "Japan is yet to reach the stage of institutionalizing citizen participation" [79]. The positive impact of greater participatory decision-making procedures on public acceptance has been documented for other large scale energy infrastructure [80-81]. Dialogue is a central component of public participation and its success or failure can dramatically alter the publics' perceptions of fairness, trust and inclusion, which in turn can impact upon support or acceptance of a development or industry. However, public participation is not without problems as we discuss later.

The suspension of nuclear energy related engagement programs in the UK and US seem to demonstrate that current forms of public engagement have largely failed. In addition, social movements in Japan are increasingly challenging the top-down, technocratic system of energy decision making, calling for more dialogue with the public. New forms are required if public consent for development is truly sought by government and other decision-makers. Amendments to UK planning and infrastructural law detailed within the 2014-2015 Infrastructure Bill are currently being reviewed in the House of Lords. The new legislation departs from the 2008 Planning Act [82] and the 2011 Localism Act [83] that aims to involve local communities in decisions which affect them. The Infrastructure Bill appears to suggest more decision-making powers being returned to the Secretary of State in order for large-scale developments, particularly in the low-carbon energy sector, to be realised. This highlights the beginning of a 'deliberative U-turn' in UK infrastructural politics, and a threat to opportunities for greater local democracy. There are also significant political uncertainties regarding a nuclear waste geological repository in the US. The States may resist "any signs that DOE is planning long-term waste storage at their sites" [84: 21-22]. To address these issues, DOE will continue to need robust public engagement, strong scientific support, and stable public consent.

\subsection{Social Groups and Communities}

It would seem an obvious point; social groups within communities have different priorities. However, this has not been acknowledged sufficiently in the literature on social sustainability. Researchers have historically not considered social sustainability from the perspective of different social groups in sufficient detail, and the various pathways of social sustainability which may exist within a community. However, a recent study by Batel and Devine Wright [43] promotes gaining a deeper understanding of how groups and individuals in different places 
perceive particular developments. To do this, they suggest that an emplacement perspective, as opposed to a siting perspective, should be taken to understand local perceptions of large scale energy infrastructures. This 'place-based' perspective would focus upon how residents, both individuals and groups, within different settlements perceived and responded to specific energy infrastructures, "referring not only to specific sites where developments are proposed, but also wider 'energy landscapes' that might be cumulatively affected by several low carbon infrastructure proposals" [ibid: 4; also see 57]. The authors also note the importance of understanding the characteristics of localities and the nature of the residents within these places to better understand response patterns to infrastructural developments, for example in regards to expected local impacts [also see 58]. They state that their research highlights the possibility of "more in-depth and context-sensitive information about people's beliefs regarding energy infrastructures" [43: p. 13] when examining individuals' responses based on "communities of locality at the local level" [ibid].

As Checkland [85] points out, human systems are better understood in terms of emergent systems of meaning that people ascribe to the world. Differences between communities have been described as "area specific and 'hidden' conditions" [86: 712], and issues of "local accuracy" and greater incorporation of "local values and priorities" [86: 713] during sustainability indicator development have been highlighted [86-87]. As Turcu [86] states, indicators are only appropriate when they are flexible, "accounting for local priorities and needs" [p. 20], and that there exists "multiple pathways to urban sustainability, as areas and communities have different circumstances and priorities" [p. 19].

How do we establish the boundaries for our various community / stakeholder groups? Responses from the various social groups in our research on public opinion of nuclear power in Anglesey, North Wales has recorded different community priorities, and demonstrated varying levels of trust of the nuclear energy industry and local government. Parry carried out research on the island of Anglesey, North Wales [88] to investigate local public opinion and perceptions of risk towards nuclear energy infrastructure. Data was gathered from questionnaires distributed by hand to three different social groups; farmers, the general public, and students aged 16-17, and responses were recorded using a five point Likert scale. Among the topics covered by the questionnaire were appropriate levels of dialogue and participation. The results recorded that a significant majority of all three social groups perceived the amount of dialogue that had taken place, between the public and 'officials' in regards to nuclear power developments, was insufficient. Regarding public participation during decision-making, farmers demonstrated significant uncertainty and disagreement towards the sufficiency of current participation levels. Both students and the general public demonstrated less disagreement than farmers, but considerable uncertainty about the appropriateness of current levels of public in nuclear infrastructure decision making. In the context of dialogue and participation as components of social sustainability, the findings are profound. This directed our thoughts to the possibility of various social and stakeholder groups within a community, 
with the potential for numerous 'social sustainability pathways' existing within a locality. The research highlights the complex nature of 'public opinion' and demonstrates variance at the community level, rejecting the singularity of the notion of 'the public'. The degree of importance of dialogue and participation to those questioned could not be deduced from the results of the above study. However, participant responses suggest that, in regards to dialogue and participation for energy developments and decision-making, significant work is required.

In this paper, we propose a change in emphasis regarding the role of the community, to establish a basis for a socially sustainable approach. This contrasts sharply with the situation in other countries such as the United States (US), particularly when decommissioning nuclear facilities. However, in both the UK and US, citizens are willing to become involved in government consultations in the hope that they will be able to obtain knowledge and perhaps influence the decision that is to be made on their behalf. The challenge to involve stakeholders in strategic level decision-making continues to be a particularly poignant issue for the UK government, the nuclear industry and new energy industries such as the recent development of shale gas in North West England.

This has led the authors to consider an approach to community level engagement and decision-making which recognises intra-community diversity, promotes trust building through neutral facilitating, seeks to understand social group priorities and visions of sustainability, and to begin developing a conceptual framework that reflects this approach. However, as our research progresses from this early stage, it would be naïve of us to ignore the possible interrelatedness of actors from different groups - for example the children of the farmers we have identified as a social group. Alternatively, if there are priority disparities between social groups, how does this impact upon achieving or working towards social sustainability within communities?

\section{Conceptual Framework Process}

The conceptual framework proposed in this paper is based on the assumption that a diverse range of social priorities is held by various stakeholder and social groups and that this is representative of the wider community. We assert that considering 'the public' as a single, uniform entity is unhelpful in regards to effective engagement so we target pre-existing social groups for our sample. As Pidgeon [89] states, there are a wide range of views in 'nuclear communities' which represent a "diverse set of publics" (p. 2). We suggest that by understanding this range of priorities and developing 'priority profiles' for different social groupings, more informed, legitimate and sustainable decisions can be made within communities. 
In terms of process, the approach presented by our conceptual framework (Fig. 1) is community led and asset based, using deliberation to generate community priorities. We aim to initiate a lasting change within communities through building social capital; focusing on community assets not deficits [90]. This approach is being used by Big Local Trust, the $£ 220 \mathrm{~m}$, 15 year UK National Lottery programme to encourage voluntary action and community development to support communities to achieve their own goals.

Methodologically, we have also adopted an action orientated approach, a cyclical process of: diagnostic research; reflection and action planning; data gathering; reflection and intervention [91] to provide structure and rigour to the research process. This approach was specifically chosen to facilitate research in a fluid situation where change is inevitable. Periods of reflection are incorporated within the research process between workshops and will allow assessment of the data in real time as participants' knowledge and views are likely to develop. Whilst recognising the relative limitations that are placed on researchers in terms of limited access to the research group, the research is action orientated with what Midgley [92] calls "action for improvement". This is the ultimate goal of the research and incorporates the purposeful action by an agent to create change.

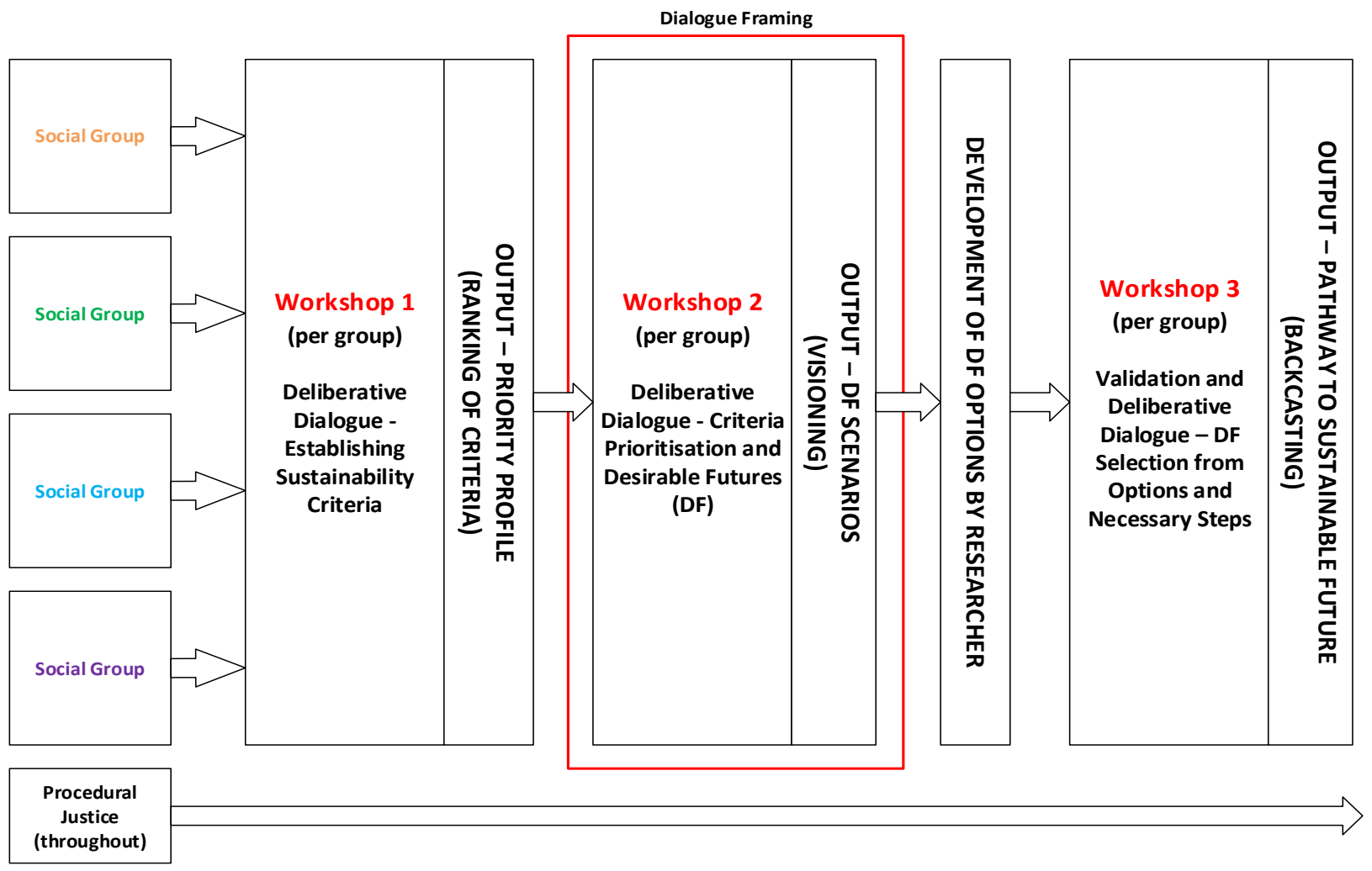

Figure 1. Conceptual framework for the establishment and prioritisation of sustainability criteria with various community-level social groups, and developing sustainable future pathways 
We will employ a community visioning process, similar to that proposed by Ames [1]. This approach comprises five steps to strategic visioning, four of which are reflected during the workshop series. The development of 'priority profiles' in Workshop 1 reflect the objectives of Step 1 (Where are we now?), developing an inventory through descriptive data, and identifying values. In Workshop 2 participants are encouraged to develop possible future scenarios (Step 2 - Where are we going?). Finally in Workshop 3, visioning and backcasting techniques are used to identify preferred sustainable futures and derive pathways to them (Step 3 - Where do we want to be? and Step 4 - How do we get there?). The fifth and final step involves implementation and monitoring (Are we getting there?), which is outside the scope of the conceptual framework presented here, but is considered as future work. We assert that an effort to maintain procedural justice throughout the process is essential, to ensure a fair and legitimate process. How this will be achieved and maintained can be discussed with groups at the beginning of the process, and revisited throughout the process, so that any notion of fairness can informed by group expectations and feedback.

Such processes have been employed previously at the local level to, for example, consider local solutions and action towards climate change [93-94], processes which can also provide opportunities to promote and accelerate participant capacity / social capital building. As Sheppard et al. [94] note, visioning approaches are based upon "improved two-way communication and information transfer" (p. 401) at community level, and aim to progress from more conventional, dis-jointed silo thinking [95] of historic planning processes employing more 'top-down' approaches. Visioning approaches commonly employ more 'bottom-up', participative methods and often utilize the experiences and knowledge of local people.

\subsection{Workshop 1}

The first workshop enables participants to identify priorities that impact on their community, whilst considering criteria that reflect participants' interests. The researchers will provide criteria based on the literature to support participants, as Whitton, Parry and Howe have suggested previously [96]. The approach intentionally promotes a 'citizen' focus to engagement, from the outset we will facilitate trust-building, cooperation and respect between participants and facilitators.

Social sustainability criteria are proposed in reports from Government, NGOs, industry [9799] and academia [24, 26, 88, 100] including commentary on the relevance and legitimacy of such criteria in their local context. In conjunction with a discussion of these criteria, participants would be encouraged to discuss their own experiences, knowledge and social priorities. A list of social sustainability criteria is developed, in the form of a 'priority profile'. We will employ a mixed methods approach [93] to gain a detailed understanding of prioritized 
issues, accepting that different participants may favour different methods. We propose this contributes to engagement that is fair and inclusive. Turcu [86] employs quantitative methods in her UK study to identify issues of local priority from those identified in previous studies. We will employ similar methods to identify group priorities, followed by the ranking of priorities by participants, in order of importance. This will highlight social group values, and intra-group variation or consensus on topics. We suggest that through the early identification of group priorities, and placing these at the centre of discussions, trust-building with communities can result, which will aid the facilitation of future dialogue. The outcome of the first workshop is a primary priority profile for each social group, the first stage of a community visioning process. This outcome will allow us to reflect on the early findings and plan the second workshop as part of our action orientated approach.

\subsection{Workshop 2}

We will facilitate the development of a community-led narrative at the second workshop, which will contextualise the community profiles; (e.g. regarding proposed energy developments). In reference to our conceptual framework, this reflects 'dialogue framing'. The priority profile of the group will be discussed within this context, to identify whether priorities change or become less or more important.

By contextualising, the group will be encouraged to deliberate and develop a series of desirable futures, representative of Step 2 (Where are we going?) of the five steps of community visioning proposed by Ames [1]. Futures will be based on a context (energy developments) and the priority profile of the group. The objective of this deliberation is to understand what futures may be desirable to each group and the social priorities such futures would be based on. We also aim to test practical methods that can support the community visioning process such as visual and graphical methods. These 'visual minutes' will be used to develop an image of the deliberation and a visual representation of a desirable future. The main outcome of the second workshop is a series of desirable future scenarios to be evaluated by the facilitation team.

As discussed previously in reference to our action orientated approach, periods of reflection are incorporated between workshops and will allow assessment of the data in real time as participants' knowledge and views are likely to develop. Considering procedural justice as an overarching theme of our work, we will demonstrate that whilst community priorities are the focus of the process we will also record how perceptions and priorities change as capacity among participants increases. This is necessary to promoting a greater sense of ownership of the visioning process and outcomes. 


\subsection{Workshop 3}

The third and final workshop provides an opportunity for each group to provide feedback on the scenario presented by the facilitation team. Each social group participant will be provided with a workshop summary to promote an awareness of how work has progressed and informed the development of scenarios. Group validation of this 'sustainable future' is important as it ensures the local legitimacy of what has been developed, and further supports the whole-process aim of achieving procedural justice.

A backcasting approach will be used to identify a development pathway in order to reach this future. Key stages will be identified by the group, working from the end scenario back to the present day, establishing what must be done to achieve this desired and sustainable future. Referring back to the five steps of strategic visioning proposed by Ames [1], this workshop reflects Step 3 (Where do we want to be?) which involves identifying preferred futures, and Step 4 (How do we get there?) which involves determining the actions which enable this future to be attained through the development of an action plan.

Developmental pathways will be generated by each social group, evaluated following the workshop series to find common inter-group themes and priorities. This will inform future engagement and public participation in the locality, promote trust building and demonstrate greater legitimacy. These pathways are not identified in order to fracture or divide a community, but to understand its complexity and work towards robust, sustainable decision making, which is legitimately informed, by locally-defined priorities and inter-generational support. We support the notion that societal differences are to be acknowledged and embraced within decision making processes. As Dryzek suggests in his promotion of a theory of discursive democracy, these processes should embrace "the necessity to communicate across difference without erasing difference" [19: 170]. This can produce a socially convergent development pathway at the local level which should be - as Dryzek proposes to be the feasible and attractive outcome of deliberation and foundation of consensus - based upon "workable agreements in which participants agree on a course of action, but for different reasons" [ibid].

\section{Discussion}

Any attempts towards the control of engagement process participants by a convening government or organization, or between participants themselves, would appear to work against those ideals of fairness and the discursive validity of the freedom to participate and influence decisions, proposed by Habermas. The author stresses the need for greater levels of participation in all areas of life where important public decisions are made, but White [101] highlights that Habermas provides us with little information on what type of institutional forms are appropriate for this purpose. We concur with Habermas, who does not propose democratic 
institutional control by its citizens, but rather that the principle of participation should act as a burden of proof on the convening organization to demonstrate why there could not be greater participation in decisions which affect citizens and communities. As Rowe and Frewer point out [50], the concept of fairness also relates to the public acceptance of a particular process of participation.

\subsection{Fairness and Justice}

We agree with Reed [59]; that the structure of a convening institution or body and its ability to institutionalize stakeholder engagement as a method to influence strategy is also fundamental to successful engagement and understanding the current approach adopted. Many of the limitations experienced in participatory processes have their roots in the organisational cultures of those who sponsor or participate in them. For example, non-negotiable positions, or as was evident in our UK research a lack of clarity regarding the influence of participants, may simply be the result of pre-determined positions decided at higher levels within the organisation, prior to participation in the process, that representatives do not feel able to negotiate.

When considering fairness within our conceptual framework, we have drawn heavily on justice theory to support our assertions regarding participation and deliberation. This is concurrent with a growing critique and emerging consensual rejection by academics of the popular NIMBY (Not In My Back Yard) perspective. It describes the behaviour of individuals who claim or appear to support, commonly, renewable energy projects in principle but oppose such developments in their local area or 'back yard' [102], often leading to hypocrisy-based criticisms. However, for more than a decade an increasing number of authors have deemed the NIMBY concept to be short sighted, simplistic and lacking in empirical and theoretical vigour, particularly in the wind power literature [102-107]. As Walter [108] asserts, the NIMBY perspective has now "largely been abandoned as a research paradigm" (p. 78).

The notion of justice, in broad legalistic terms, relates to fairness and righteousness [109, cited in 10]. When considered in terms of energy and societies, the definition becomes gains complexity and integrates numerous themes. In their recent article on socio-energy systems, Miller, Richter and O'Leary [110] describe the nature of energy systems and energy transitions as being deeply socially, economically and politically embedded. They describe justice in terms of human outcome distribution, i.e. power and voice distribution within energy decisionmaking and the deeper energy-society relationships which emerge from their interaction. In constructing our conceptual framework, we have incorporated this notion of the distribution of power and voice in decision-making, promoting greater understanding and centralisation of local issues and place-based matters to facilitate increased legitimacy and justice during decision-making processes. We propose a communicative power-shift during these processes, 
whereas local context and the priorities of local people are central within 'upstream', primary level discussions, as opposed to the dominance of expert-level discussions establishing the energy-related 'problems' or 'challenges' at hand, in absence of place-based considerations and citizen perspectives. This works to further acknowledge the integrated relationship of energy systems and local societies, the importance of meaningful engagement with 'affected citizens', and the criticality of realising and ensuring justice for citizen groups throughout decision-making processes.

Distributive and procedural justice are also examples of themes we have been found to be important, explanatory factors in research concerned with energy-related policy and decisionmaking and stakeholder engagement processes. Whitton [9] concentrates on the dialogue used to engage participants and a concept of fairness, by empowering stakeholders not just to consider whether a meeting or process has been a 'success', but also to consider their role in the dialogue process and how they perceive their influence on the decisions made. Influence through deliberation is considered by the author to add to this concept of fairness. By moving away from purely technocratic decision-making towards a deliberative model of engagement informed by technical specialists, stakeholders can realize a level of influence through fair and socially sustainable dialogue. This is discussed in terms of the reciprocity; between stakeholders involved in the engagement process and the decisions made.

As Walter [108] notes, theories of distributive justice explain perceptions of fairness relating to the distribution of outcomes from specific resources or projects, where fairness may be assessed by comparing outcome distributions against principles of fairness such as equity and need (e.g. [111]). Others describe distributive justice as relating to individual perceptions of fairness regarding outcome distributions or allocations [10]. In contrast, theories of procedural justice are concerned with individual perceptions of fairness towards processes and decisionmaking procedures (ibid), and are explained by structural and relational models [108]. Structural models demonstrate how perceived justice is influenced by "structural procedure characteristics" (ibid: 78), such as during public engagement processes, whereas relational models are concerned with the development of sustainable relationships between authorities and citizens, through an understanding of the characteristics and behaviour of authorities (e.g. [112, cited in 108], which can impact stakeholder trust and support.

\subsection{Place-based Approaches}

Our framework clearly supports a context-based approach as the most appropriate so as to ensure procedural legitimacy and ultimately, greater public support. Wolsink [113] argues that case-specific variables are most critical in order to achieve local acceptance, and the utilisation of general attitudes towards a technology should be avoided in predicting local acceptance of wind projects. Batel and Devine-Wright [43] (2015), in their work on public responses to large 
scale energy infrastructures, suggest that instead of a site-based approach, a place-based approach may be more beneficial for understanding people's beliefs about energy infrastructures, by gathering and utilising more in-depth and context-specific information. As Pidgeon and Demski [114] highlight, understanding and considering the different characteristics of places and how places are constructed by those who live there is important to understand response patterns to large-scale infrastructures. More recently, Batel and DevineWright [43] suggest that policies for infrastructural deployment, and indeed public support for developments, may be impacted by an approach which enables greater understanding of public responses in different places. Therefore, in association with our conceptual framework which promotes a priority-based approach identifying local conditions and values, we suggest that a 'case and place-based' approach would assist in facilitating more legitimate decision-making and contribute towards social sustainability locally through increased trust and empowerment. We propose that the structural procedure characteristics of such an approach - a priority-based approach, utilising in-depth, context-specific information to place local stakeholders and 'case and place-based' constructs at the core of dialogue during decision-making - result in greater procedural justice through increased perceptions of relevance and legitimacy, acknowledgement of local context, and stakeholder involvement.

As Miller, Richter and O'Leary [110] point out, for many decades energy policy institutions have operated out of the public eye and with minimal public involvement, and now face new challenges as the public becomes more attentive and responsive to energy choices. Transitions in socio-energy systems, particularly concerning large-scale energy infrastructure and contentious technologies such as nuclear power, produce wide ranging social impacts and result in power reconfigurations across communities. These have led to widespread social protest and conflict surrounding energy policy decisions [ibid], realities which further support a shift to an approach to local decision-making, as we propose, promoting greater aspects of procedural justice. The conceptual framework encourages decision-making facilitators to become familiar with those local stakeholder groups potentially impacted more greatly by the socio-energy systems which they inhabit and the transitions occurring within them.

\subsection{Socio-energy Systems}

Miller et al. [110] suggest four strategic directions to transform energy policy into processes for socio-energy system design. One of these avenues - socializing energy policy - proposes the need for new strategies to integrate human and social dimensions into "processes of energy design, planning, and policy-making", requiring "understanding, acknowledging, and incorporating the ways in which people inhabit energy systems" (p. 36). Our conceptual framework demonstrates a contribution towards such an objective, through its focus on understanding local stakeholder group priorities, values and preferences and contributing this knowledge into energy-related decision-making. It provides further opportunity to understand 
how individuals inhabit and perceive socio-energy systems and any changes, such as new infrastructural developments, occurring within these systems. A second avenue proposed by the authors - publicizing energy policy - is also contributed to by the approach proposed here, in its engagement of stakeholder groups and consideration of how energy changes are to impact upon these publics. As Devine-Wright [81] highlights, people are increasingly aware of energy system transformations, and of their potential impacts, and are therefore increasingly demanding to participate in and influence energy policy. Despite this, and whilst acknowledging that future socio-energy systems should be envisioned and designed through energy industry and community collaborations, Miller et al. [110] identify challenges surrounding developing new methodologies to devise "future energy pathways on multiple scales and temporalities" (p. 37), concurrent to the dearth of opportunities available to communities to become engaged in such strategic processes. We propose that our conceptual framework approach contributes towards these 'publicising' objectives within socio-energy systems, through deliberative engagement with local stakeholders and facilitating a dialogue in which their priorities and visions for the future are understood and utilised in decisionmaking processes.

The literature highlights a community-led desire to become more involved in decisionmaking processes, particularly regarding large-scale developments which can potentially impact upon the social, environmental and economic fabric of society [34, 115-118]. Continuing at the current level of community participation in decision-making may negatively impact upon the social sustainability of local communities, such as Anglesey, if decisions are made without those whom they impact upon most greatly, or without their tangible influence. The conceptual framework proposed for social sustainability represents a radical shift in the organisational culture of government agencies and other institutions. Clearly, access to and how citizens engage with institutions and decision-makers is an important aspect of social sustainability and will form the basis of our future research.

\section{Conclusions}

Despite public engagement initiatives to discuss energy developments, there is currently an absence of process or appropriate dialogue to illicit a sustainable community response to the planned closure of many energy generation sites or the development of new energy infrastructure, such as shale gas in the UK. We propose a systemic, community led, asset based approach to societal dialogue; one that captures the views and concerns of the wider stakeholder community and is able to inform views / decision-making at the community level and inform strategic levels of decision-making. Our conceptual framework will allow us to derive a systemic view of community-led priorities - that is, the social construction of affected communities. In addition, it will allow us to contribute to a concept of fairness when engaging with communities. 
This community-led conceptual framework for social sustainability operates on two levels. The first allows communities to define their priorities and understand how social sustainability may be constructed, as either as a social group or as a community collective of individuals. The second is to produce clear views from the community to inform institutional and governmental decision-makers. To achieve this, we will carry out action orientated research, epistemologically similar to that outlined by Whitton [46]. We are currently in the process of testing the framework and the validity of criteria and have recently completed fieldwork in Anglesey, North Wales with young people to discuss a wide range of energy perception issues - not least their views on energy developments and sustainable communities. 


\section{References}

[1] Ames S. Community visioning. In: Steiner FR and Butler K (Eds). Planning and urban design standards (pp.39-40). Hoboken, NJ: John Wiley and Sons; 2006.

[2] Cuthill M. Strengthening the 'Social' in Sustainable Development: Developing a Conceptual Framework for Social Sustainability in a Rapid Urban Growth Region in Australia. Sust Dev 2010; 18: 362 - 73. DOI: http://dx.doi.org/10.1002/sd.397

[3] Lapachelle P, Emery M, Hays RL. The pedagogy and the practice of community visioning: evaluating effective community strategic planning in rural Montana. Commun Dev 2010; 41 (2): $176-191$.

[4] McKinlay P. The challenge of democratic participation in the community development process. Commun Dev J 2006; 41 (4): 492 - 505.

[5] Murtagh B. City visioning and the turn to community: The case of Derry/Londonderry. Plan Prac Res 2001; 16 (1): 9 - 19.

[6] Webler T, Tuler S, Kreuger R. What Is a Good Public Participation Process? Five Perspectives from the Public. Environ Manag 2001; 27 (3): 435 - 50. DOI: http://dx.doi.org/10.1007/s002670010160

[7] Magis K, Shinn C. Emergent themes of social sustainability. In: Dillard J, Dujon V, King MC. (Eds) Understanding the Social Aspect of Sustainability. New York: Routledge; 2009.

[8] Whitton J. Stakeholder Participation for the Legacy Ponds and Legacy Silos (LP\&LS) Facility at Sellafield, Cumbria, UK: The Nature and Effectiveness of the Dialogue. Proceedings of ICEM '09 (2009, 11 - 15 October: Liverpool, UK).

[9] Whitton J. Participant Perceptions on the Nature of Stakeholder Dialogue Carried Out by the Nuclear Decommissioning Authority (NDA) [PhD Thesis]. University Of Manchester, $\mathrm{UK} ; 2010$.

[10] Walker BJA, Wiersma B, Bailey E. Community benefits, framing and the social acceptance of offshore wind farms: An experimental study in England. Energy Res Soc Sci 2014; 3: 46 - 54. DOI: http://dx.doi.org/10.1016/j.erss.2014.07.003 
[11] Lawless WF, Akiyoshi M, Angjellari-Dajci F, Whitton J. Public consent for the geological disposal of highly radioactive nuclear wastes and spent nuclear fuel. Int J Env Stud 2014; 71 (1), 41 - 62. DOI: http://dx.doi.org/10.1080/00207233.2014.881165

[12] Innes JE, Booher DE. Reframing Public Participation: Strategies for the $21^{\text {st }}$ Century. Plan Theory Pract 2004; 5 (4): $419 \quad-\quad 36 . \quad$ DOI: http://dx.doi.org/10.1080/1464935042000293170

[13] Lake RW, Hanson S. Needed: Geography Research on Urban Sustainability. Urban Geog 2000; 21(1): 1 - 4. DOI: http://dx.doi.org/10.2747/0272-3638.21.1.1

[14] Yitfachel O, Hedgcock D. Urban social sustainability: The planning of an Australian city. Cities 1993; 11 (2): 139 - 57. DOI: http://dx.doi.org/10.1016/0264-2751(93)90045-K

[15] Jones R, Tonts M. Rural restructuring and social sustainability: some reflections on the Western Australian wheatbelt. Aust Geog 1995; 26 (2): 133 - 40. DOI: http://dx.doi.org/10.1080/00049189508703142

[16] Raven RPJM, Jolivet E, Mourik RM, Feenstra YCFJ. ESTEEM: Managing societal acceptance in new energy projects. A toolbox method for project managers. Technol Forecast Soc Change 2009; 76: $963-77$. DOI: http://dx.doi.org/10.1016/j.techfore.2009.02.005

[17] Raven RPJM, Mourik RM, Feenstra YCFJ, Heiskanen, E. Modulating societal acceptance in new energy projects: Towards a toolkit methodology for project managers. Energy 2009; 34: 564 - 74. DOI: http://dx.doi.org/10.1016/j.energy.2008.08.012

[18] Beck U, Giddens A, Lash S. Reflexive Modernization. Politics, Tradition and Aesthetics in the Modern Social Order. Stanford University Press, 1994.

[19] Dryzek J.S. Deliberative Democracy and Beyond: Liberals, Critics, Contestations. Oxford, UK: Oxford University Press, 2000.

[20] Flood RL. The Relationship of Systems Thinking to Action Research. Syst Prac Act Res 2010; 23: 269 - 84. DOI: http://dx.doi.org/10.1007/s11213-010-9169-1

[21] Jackson MC. Systems methodology for the management sciences. New York: Plenum; 1991

[22] Welch C. Guest Editorial to Special Edition. Syst 2009; 31 (2\&3): 43 - 44. 
[23] Bijl R. Never Waste a Good Crisis: Towards Social Sustainable Development. Soc Indic Res 2011; 102: 157 - 68. DOI: http://dx.doi.org/10.1007/s11205-010-9736-y

[24] Sachs I. Social sustainability and whole development: exploring the dimensions of sustainable development. In: Egon B, Thomas J. (Eds.) Sustainability and the social sciences: a cross-disciplinary approach to integrating environmental considerations into theoretical reorientation (pp. 25 - 36). London: Zed Books; 1999.

[25] Littig B, Grießler E. Social sustainability: a catchword between political pragmatism and social theory. Int J Sust Dev 2005; 8 (1/2): 65 - 76. DOI: http://dx.doi.org/10.1504/IJSD.2005.007375

[26] Dempsey N, Bramley G, Power S, Brown C. The Social Dimension of Sustainable Development: Defining Urban Social Sustainability. Sust Dev 2011; 19: 289 - 300. DOI: http://dx.doi.org/10.1002/sd.417

[27] Vallance S, Perkins HC, Dixon JE. What is social sustainability? A clarification of concepts. Geoforum 2011; 42: $342-48$.

[28] Devine-Wright P, Devine-Wright H, Sherry-Brennan F. Visible technologies, invisible organisations: An empirical study of public beliefs about electricity supply networks. Energy Policy 2010; 38: 4127 - 34. DOI: http://dx.doi.org/10.1016/j.enpol.2010.03.039

[29] Krütli P, Stauffacher M, Flüeler T, Scholz RW. Functional-dynamic public participation in technological decision-making: site selection processes of nuclear waste repositories. $\mathrm{J}$ Risk Res 2010; 13 (7): 861 - 75. DOI: http://dx.doi.org/10.1080/13669871003703252

[30] Cotton M, Devine-Wright P. Putting pylons into place: a UK case study of public perspectives on the impacts of high voltage overhead transmission lines. J Environ Plan Manag 2012; 56 (8): 1225 - 45. DOI: http://dx.doi.org/10.1080/09640568.2012.716756

[31] Cotton M, Devine-Wright P. Making electricity networks "visible": Industry actor representations of "publics" and public engagement in infrastructure planning. Public Underst Sci 2012; 21 (1): 17 - 35. DOI: 10.1177/0963662510362658

[32] Cowell R, Bristow G, Munday M. Acceptance, acceptability and environmental justice: the role of community benefits in wind energy development. J Environ Plan Manag 2011; 54 (4): 539 - 57. DOI: http://dx.doi.org/10.1080/09640568.2010.521047 
[33] Rojanamon R, Chaisomphob T, Bureekul T. Public Participation in Development of Small Infrastructure Projects. Sust Dev 2012; 20: $320-34$. DOI: http://dx.doi.org/10.1002/sd.473

[34] Shamsuzzoha AHM, Grant A, Clarke J. Implementation of renewable energy in Scottish rural area: A social study. Renew Sust Energy Rev 2012; 16: 185 - 91. DOI: http://dx.doi.org/10.1016/j.rser.2011.07.146

[35] Lidskog R, Sundqvist G. On the right track? Technology, geology and society in Swedish nuclear waste management. J Risk Res 2004; 7 (2): 251 - 68. DOI: http://dx.doi.org/10.1080/1366987042000171924

[36] Dawson JI, Darst RG. Meeting the Challenge of Permanent Nuclear Waste Disposal in an Expanding Europe: Transparency, Trust and Democracy. Environ Politics 2006; 15 (4): 610 - 27. DOI: http://dx.doi.org/10.1080/09644010600785226

[37] WCMRWS (West Cumbria Managing Radioactive Waste Safely Partnership). The Final Report of the West Cumbria Managing Radioactive Waste Safely Partnership. Published by Copeland Borough Council, Copeland, UK; August 2012 [Available at: http://www.westcumbriamrws.org.uk/images/final-report.pdf] [Accessed 12/02/13].

[38] Aas Ø, Devine-Wright P, Tangeland T, Batel S, Ruud A. Public beliefs about high-voltage powerlines in Norway, Sweden and the United Kingdom: A comparative survey. Energy Res Soc Sci 2014; 2: 30 - 37. DOI: http://dx.doi.org/10.1016/j.erss.2014.04.012

[39] Walker G. Renewable energy and the public. Land Use Policy 1995; 12: 49 - 59.

[40] Wustenhagen R, Wolsink M, Burer MJ. Social acceptance of renewable energy innovation: An introduction to the concept. Energy Policy 2007; 35: 2683 - 91.

[41] Burningham K. Using the language of NIMBY: a topic for research, not an activity for researchers. Local Environ Int J Justice Sust 2000; 5: 55 - 67.

[42] Devine-Wright P. Rethinking NIMBYism: the role of place attachment and place identity in explaining place-protective action. J Commun Appl Soc Psychol 2009; 19: 426 - 41.

[43] Batel S, Devine-Wright P. A critical and empirical analysis of the national-local 'gap' in public responses to large-scale energy infrastructures. J Environ Plan Manage 2015; 58 (6): $1076-1095$. 
[44] Aaltonen K, Jaakko K, Tuomas, O. Stakeholder Salience in Global Projects. Int J Proj Manag 2008; 26: 509 - 16. DOI: http://dx.doi.org/10.1016/j.ijproman.2008.05.004

[45] Mitchell RK, Agle BR, Wood DJ. Toward a Theory of Stakeholder Identification and Salience: Defining the Principle of Who and What Really Counts. Acad Manag Rev 1997; 22 (4): $853-86$.

[46] Whitton J. Emergent Themes in Nuclear Decommissioning Dialogue: A Systems Perspective. Syst 2011; 33 (2/3): 132 - 49

[47] Shapiro, I., (1999). Enough of deliberation: politics is about interest and power. In: S. Macedo (Ed.), Deliberative Politics: Essays on Democracy and Disagreement, 28 - 38. New York: Oxford University Press.

[48] Mendelberg, T., (2002). The Deliberative Citizen: Theory and Evidence. Political Decision Making, Deliberation and Participation, Volume 6, 151 - 193.

[49] Rossi, J., (1997) Participation Run Amok: The Costs of Mass Participation for Deliberative Agency Decision-making. Northwestern University Law Review, 92, 173 249.

[50] Rowe G, Frewer LJ. A Typology of Public Engagement Mechanisms. Sci Tech Hum Val; 30 (2): $251-290$.

[51] Beierle TC. The Quality of Stakeholder - Based Decisions. Risk Anal 2002; 22 (4): 739 - 49. DOI: http://dx.doi.org/10.1111/0272-4332.00065

[52] Rowe G, Frewer LJ. Public Participation Methods: A Framework for Evaluation. Sci Tech Hum Values 2000; 25 (1): 3 - 29. DOI: http://dx.doi.org/10.1177/016224390002500101

[53] De Marchia B and Ravetz JR. Risk management and governance: a post-normal science approach. Futures 1999; 31: 743-757.

[54] Funtowicz SO and Ravetz JR. Science For The Post-Normal Age. Futures 1993 (Sept); $739-755$.

[55] Ravetz JR. The post-normal science of precaution. Futures 2004; 36: 347 - 357

[56] Ravetz JR. Post-Normal Science and the complexity of transitions towards sustainability. Ecol Compl 2006; 3: 275 - 284. 
[57] Buhr K. and Wibeck V. Communication approaches for carbon capture and storage: Underlying assumptions of limited versus extensive public engagement. Energy Res Soc Sci 2014; 3: 5 - 12

[58] Irvin R, Stansbury J. Citizen participation in decision making: is it worth the effort? Public Admin Rev 2004; 64: 55-65.

[59] Reed MS. Stakeholder Participation for Environmental Management: A Literature Review. Biol Conserv 2008; 141: $2417-31$. DOI: http://dx.doi.org/10.1016/j.biocon.2008.07.014

[60] Habermas J. Towards a Theory of Communicative Competence. Inq 1970; 13: 363 - 72.

[61] Habermas J. Theory of Communicative Action, Vol. 2: Reason and the Rationalization of Society. Boston: Beacon Press; 1987.

[62] van Stokkom B. Deliberative Group Dynamics: Power, Status and Affect in Interactive Policy Making. Policy Polit 2005; 33 (3): 387 - 409. DOI: http://dx.doi.org/10.1332/0305573054325701

[63] Cabinet Office. Consultation Principles. Crown Copyright; $17^{\text {th }}$ July 2012 [Updated $5^{\text {th }}$ November 2013]. Available at: [https://www.gov.uk/government/publications/consultation-principles-guidance] [Accessed 25/04/14].

[64] Bond A, Palerm J, Haigh, P. Public Participation in EIA of nuclear power plant decommissioning projects: a case study analysis. Environ Impact Assess Rev 2004; 24 : 617 - 41. DOI: http://dx.doi.org/10.1016/j.eiar.2004.02.002

[65] Kemp RV, Bennett DG, White MJ. Recent trends and developments in dialogue on radioactive waste management: Experience from the UK. Environ Int 2006; 32: 1021 32.

[66] Cuppen E, Breukers S, Hisschemöller M, Bergsma E. Q methodology to select participants for a stakeholder dialogue on energy options from biomass in the Netherlands. Ecol Econ 2010; 69: 579 - 91. DOI: http://dx.doi.org/10.1016/j.ecolecon.2009.09.005

[67] Evans B, Parks J, Theobald K. Urban wind power and the private sector: community benefits, social acceptance and public engagement. J Environ Plan Manag 2011, 54 (2): 227 - 44. DOI: http://dx.doi.org/10.1080/09640568.2010.505829 
[68] Energy Act 2004. The Stationary Office, London.

[69] DECC. Written ministerial statement by Edward Davey on the management of radioactive waste. $31^{\text {st }} \quad$ January $2013 . \quad$ Available at: [https://www.gov.uk/government/speeches/written-ministerial-statement-by-edwarddavey-on-the-management-of-radioactive-waste] [Accessed on 24/04/14]

[70] Lawless WF, Bergman M, Feltovich N. Consensus-seeking versus truth- seeking. ASCE Haz Tox Rad Wastes 2005; 9 (1): 59- 70. DOI: http://dx.doi.org/10.1061/(ASCE)1090$\underline{025 X(2005) 9: 1(59)}$

[71] US DOE SSAB 2008. Available online at: [www.em.doe.gov/Pages/ssab.aspx] (accessed 21/09/08).

[72] Bradbury JA, Branch KM, Malone EL. An evaluation of DOE-EM Public Participation Programs (PNNL-14200). Online Report; 2003. Available from [http://www.pnl.gov/main/publications/external/technical_reports/pnnl-14200.pdf]

[73] CEC. White Paper 2001. European Governance (COM (2001) 428 final; Brussels, 25.7.2001). Brussels: Commission of the European Community.

[74] US DOE-SRS-CAB. 2008. DOE Savannah River Site Citizens Advisory Board website [Available online at: http://cab.srs.gov/srs-cab.html] [Accessed 02/05/14].

[75] Holmes OW. Dissent: Abrams v. United States; 1919.

[76] Robertson PJ, Choi T. Deliberation, Consensus and Stakeholder Satisfaction. Public $\begin{array}{lllllll}\text { Manage } & \text { Rev } & 2012 ; & 14 & \text { (1): } 83 \quad \text { DOI: }\end{array}$ http://dx.doi.org/10.1080/14719037.2011.589619

[77] Cabinet Office. A summary of opinion poll about nuclear power. ("Genshiryoku ni kansuru tokubetsu yoron chosa no gaiyou.") Cabinet Office, The Government of Japan; 2009.

[78] Ishibashi K. Earthquake Induced Nuclear Power Plant Failure (“Genpatsu Shnisai”). Kagaku, 1997; 67: 720 - 24.

[79] Wakamatsu Y. Civic Engagement ("Sanka suru shimin.”); 2005 [Available at: http://www.nsr.go.jp/archive/jnes/tokushu/taiwa3/index.html ] [Accessed 21/04/14] 
[80] Bell D, Gray T, Haggett C. Policy, participation and the 'social gap' in wind farm siting decisions. Env Polit 2005; 14 (4): 460 - 77. DOI: http://dx.doi.org/10.1080/09644010500175833

[81] Devine-Wright P. Renewable Energy and the Public: From NIMBY to Participation. London, UK: Earthscan; 2011.

[82] Planning Act 2008, Chapter 29. London, The Stationary Office.

[83] Localism Act 2011, Chapter 20. London, The Stationary Office.

[84] BRC. Blue Ribbon Commission on America's Nuclear Future. Report (Final) to the Secretary of Energy, 2012. Washington, DC

[85] Checkland PB. Systems Thinking, Systems Practice. Chichester: Wiley; 1981.

[86] Turcu C. Re-thinking sustainability indicators: local perspectives of urban sustainability. J Environ Plan Manag 2013; 56 (5): 695 - 719 . DOI: http://dx.doi.org/10.1080/09640568.2012.698984

[87] Reed M, Dougill AJ. Participatory selection process for indicators of rangeland condition in the Kalahari. Geog J 2002; 168 (3): 224 - 34. DOI: http://dx.doi.org/10.1111/1475$\underline{4959.00050}$

[88] Parry IM. Public opinion and perceptions of risk towards local nuclear power in Anglesey, north Wales [MSc Thesis]. Keele University, UK; 2011

[89] Pidgeon N. Memorandum on Public Attitudes and Nuclear Power. House of Lords Science and Technology Committee Inquiry on 'Nuclear R\&D Capabilities'. $28^{\text {th }}$ June 2011.

[90] NCVO. Big Local: the early years; 2015.

[91] Coghlan D, Brannick T. Doing Action Research in Your Own Organization. Sage Publications: London; 2005.

[92] Midgley G. Science as Systemic Intervention: Some Implications of Systems Thinking and Complexity for the Philosophy of Science. Syst Practice Action Res 2003; 16 (2): 77 -97 .

[93] Shaw A, Sheppard SRJ, Burch S, Flanders D, Wiek A, Carmichael J, Robinson J, Cohen S. Making local futures tangible - Synthesizing, downscaling, and visualizing climate 
change scenarios for participatory capacity building. Glob Env Change 2009; 19: 447 463.

[94] Sheppard SRJ, Shaw A, Flanders D, Burch S, Wiek A, Carmichael J, Robinson J, Cohen S. Future visioning of local climate change: A framework for community engagement and planning with scenarios and visualization. Futures 2011; 43: $400-412$.

[95] Busby P. Carbon neutrality: Now is the time for action. Renew Canada Letters 2009; 5. In: Sheppard SRJ, Shaw A, Flanders D, Burch S, Wiek A, Carmichael J, Robinson J, Cohen S. Future visioning of local climate change: A framework for community engagement and planning with scenarios and visualization. Futures 2011; 43: 400 - 412.

[96] Whitton J, Parry IM, Howe JM. Social Sustainability: Participant-led Dialogue as a Basis for the Development of a Conceptual Framework for Energy Infrastructure Decisions. The Int J Sust Policy Pract 2014; 9 (3): $1-13$. Available at: [http://ijspp.cgpublisher.com/product/pub.274/prod.78]

[97] DEFRA. Measuring Progress: Sustainable Development Indicators 2010. National Statistics Compendium. Crown Copyright, 2010. [Available at: http://sd.defra.gov.uk/documents/SDI2010_001.pdf] [Accessed 13/08/2012]

[98] ODPM. The Egan Review: skills for sustainable communities. Office of the Deputy Prime Minister: London; 2004.

[99] OECD. Society at a Glance 2011 - OECD Social Indicators. The Organisation for Economic Co-operation and Development; 2011 [Available at: www.oecd.org/els/social/indicators/SAG] [Accessed 29/08/12].

[100] Colantonio A. Social Sustainability: An exploratory Analysis of its Definition, Assessment Methods, Metrics and Tools. OISD (EIB) (Oxford Institute for Sustainable Development) (European Investment Bank) Working Paper No.1; 2007

[101] White SK. Reason and Authority in Habermas: A Critique of the Critics. Am Polit Sci Rev 1980; 74 (4): $1007 \quad-\quad 17 . \quad$ Available at: [http://www.jstor.org/stable/1954320?origin=JSTOR-pdf] [Accessed 09/10/14].

[102] Petrova MA. NIMBYism revisited: public acceptance of wind energy in the United States. Wiley Int Rev: Clim Change 2013 (Nov/Dec); 4 (6): 575 - 601

[103] Devine-Wright P. Local aspects of UK renewable energy development: exploring public beliefs and policy implications. Loc Env: Int. J. Just Sust 2005; 10 (1): 57 - 69. 
[104] Devine-Wright P. Rethinking NIMBYism: The Role of Place Attachment and Place Identity in Explaining Place-protective Action. J. Community Appl. Soc. Psychol. 2006; 19: $426-441$

[105] Jones CR, Eiser JR Identifying predictors of attitudes towards local onshore wind development with reference to an English case study. Energy Pol 2009; 37: 4604-4614

[106] Wolsink M. Wind power and the NIMBY-myth: institutional capacity and the limited significance of public support. Renew Energy 2000; 21: 49 - 64.

[107] Wolsink M. Wind power implementation: The nature of public attitudes: Equity and fairness instead of 'backyard motives'. Renew Sust Energy Rev 2007; 11: 1188-1207

[108] Walter G. Determining the local acceptance of wind energy projects in Switzerland: The importance of general attitudes and project characteristics. Energy Res Soc Sci 2014, 4: $78-88$.

[109] Macquarie CCH. The CCH Macquarie Dictionary of Law. CCH Australia Limited: Sydney; 1996. In Walker BJA, Wiersma B, Bailey E. Community benefits, framing and the social acceptance of offshore wind farms: An experimental study in England. Energy Res Soc Sci 2014; 3: 46 - 54. DOI: http://dx.doi.org/10.1016/j.erss.2014.07.003

[110] Miller CA, Richter J and O'Leary J. Socio-energy systems design: A policy framework for energy transitions. Energy Res Soc Sci 2015; 6: 29 - 40.

[111] Skitka LJ, Winquist J, Hutchinson S. Are outcome fairness and outcome favorability distinguishable psychological constructs a meta-analytic review. Soc Just Res 2003; 16 (4): 309-41. In Walker BJA, Wiersma B, Bailey E. Community benefits, framing and the social acceptance of offshore wind farms: An experimental study in England. Energy Res Soc Sci 2014; 3: 46 - 54. DOI: http://dx.doi.org/10.1016/j.erss.2014.07.003

[112] Tyler TR, Lind EA. A relational model of authority in groups. In: Zanna MP, (Ed) Advances in Experimental Social Psychology, vol. 25. San Diego, CA: Academic Press; 1992. p. 115-91

[113] Wolsink M. Undesired reinforcement of harmful 'self-evident truths' concerning the implementation of wind power. Energy Policy 2012; 48: 83 - 87.

[114] Pidgeon N, Demski C. From Nuclear to Renewable: Energy Systems Transformation and Public Attitudes. Bullet Atom Scient 2012; 68 (4): 1 - 12. 
[115] Bronfman NC, Jiménez RB, Arévalo PC, Cifuentes LA. Understanding social acceptance of electricity generation sources. Energy Policy 2012; 46: 246 - 52. DOI: http://dx.doi.org/10.1016/j.enpol.2012.03.057

[116] Doukas H, Karakosta C, Flamos A, Psarras J. Electric power transmission: An overview of associated burdens. Int $\mathrm{J}$ Energy Res 2011; 35: 979 - 88. DOI: http://dx.doi.org/10.1002/er.1745

[117] Glasson J. Better monitoring for better impact management: the local socio-economic impacts of constructing Sizewell B nuclear power station. Impact Assess Project Apprais 2005; 23 (3): 215 - 26. DOI: http://dx.doi.org/10.3152/147154605781765535

[118] Rogers JC, Simmons EA, Convery I, Weatherall A. Public perceptions of opportunities for community-based renewable energy projects. Energy Policy 2008; 36: 4217 - 26. DOI: http://dx.doi.org/10.1016/j.enpol.2008.07.028 